\title{
TODA EMBROIDERY
}

\author{
CAROLIN BABY ${ }^{1} \&$ SUSAN PAUL ${ }^{2}$ \\ ${ }^{I}$ Faculty, Institute of Fashion Technology Kerala (IFTK), Government of Kerala \\ ${ }^{2}$ Professor and Head, Textiles and Apparel Designing, Sam Higginbottom Institute of Agriculture, \\ Technology and Science, Allahabad, Utter Pradesh, India
}

\begin{abstract}
India is world famous for its rich heritage and traditional textiles, magnificent workmanship. Each state in the country is unique by itself, as far as textile and embroidery is concerned. This is mainly because of the difference in the ethnicity of people, availability of the indigenous textile materials; influence of ecology, customs tradition etc. It also symbolizes the identity of the ethnic group. Tribal people of India have always had a great flair for decoration and ornamentation. However, their traditional crafts are less known to the outside world. The present study was undertaken with the aim to study socio economic status of Todas and specific information about Toda embroidery.

KEYWORDS: Rich Heritage and Traditional Textiles \& Magnificent Workmanship
\end{abstract}

Received: Apr 14, 2017; Accepted: May 05, 2017; Published: May 31, 2017; Paper Id.: IJTFTJUN20172

\section{INTRODUCTION}

India is a country with rich culture, tradition, art, music, literature and sculpture and exhibit unity in diversity through various charms of festivals, rituals, art, music, costume and languages. India is world famous for its rich heritage, traditional textiles and magnificent workmanship. It also symbolizes the identity of the ethnic group.

India has the largest variety of tribal communities, which are at various stages of socioeconomic development. At one extreme, there are groups who lead a relatively selected and archaic mode of life, keeping their core culture intact, while at the other extreme there are communities which are indistinguishable from general agricultural communities. The tribal people express their cultural identity and distinctiveness through, language, rituals, festivals and their dress, ornaments art and craft. Tribal people of the world over have always had a great flair for decoration and ornamentation. India has the rich culture and tradition of tribal embroidery. Banjara tribes of Gujarat, Rajasthan, Andhra Pradesh, Rabari Tribes of Giri region, Ahri pastoral tribes, Lambadis(Gipsy Tribes), tribal people of Assam and Todas of Nilgiri are doing embroidery on their various garments.

In India, Todas are found in the Nilgiri district of Tamilnadu state. The Toads are a small community, who live on the isolated Nilgiri plateau. The name "Toda" is said to have come from the Kannada "tudi" or "top". "Tudavar" or "Todavar" means "Those who are on the top". The Todas traditionally live in settlements, consisting of several small thatched houses, constructed in the shape of half barrels and spread across the Nilgiris areas. They are primarily cattle herders and trade dairy products within the Nilgiri district. The language of Todas is also referred to as "Toda" which is defined as a Dravidian language. Todas are vegetarians and dairy products consumed in all forms. Toda tribes are also famous for their unique embroidery called 'Toda embroidery' which is 
a less known craft to the outside world.

The Toda women, during their leisure time engage themselves in indigenous embroidery, where a coarse, unbleached hand woven white cotton cloth is embroidered with 'Pukaor' (motif) basically in geometrical forms of flower, animal and natural objects. The embroidered shawl is called "Puthkuli" and they use steel needles and woolen threads, chiefly of black and red colors. The unbleached nature of hand woven white cloth helps in identifying the yarn gauge (count of threads) quite easily. The design of 'puthkuli' is laid out in between the stripes of black and red. The patterns of 'puthkuli' are embroidered by the combined methods of darning and embroidery. As the Toda embroidery is woven out in an intricate manner by means of darning, counting of threads and or yarn gaps, the resultant design emerges as geometric forms at a casual glance which makes it distinct from other embroideries. It is very important to note that the artisans do the embroidery without transferring the design onto the fabric surface and also not referring any book. For them it is the co-ordination of mind and hand. Thus, the Toda embroidery appears striking with its bold colour scheme and complex combination of weaving and embroidery. Young Toda girls inherit the craft by observing the works done by the elders of the community.

The motifs are inspired by nature and daily life. The main motif is the buffalo horn as the Todas worship buffalos. Other designs include wild flowers, mountains, and valleys. To suit modern taste and needs a variety of items like cell phone pouches, table clothes, scarf, shawl, drawstring purse, bag, waist coat etc. are also made.

Toda tribes are very seclusion in nature and very few people know about this tribe and their unique embroidery. Few efforts are being taken by government and NGO's to preserve Toda embroidery art. However, much needs to be done to showcase their skills to the outside world. Since Toda tribes are reducing rapidly their embroidery also is in danger of becoming extinct.

Thus, the present study focuses collecting data on traditional Toda embroidery techniques, its various designs and method of application on traditional puthkuli shawls and socio economic culture of Todas of Nilgiri district of Tamilnadu. It also aims at making the indigenous art known to the outside world.

\section{METHODOLOGY}

Focus Group Interview for Collecting Information on Socio Economic Background of Todas and Their Traditional Embroidery

The present investigation is an attempt to study the Toda embroidery of Nilgiri Hills Tamilnadu. A survey was conducted to find out the embroidery art made by the Todas. Detailed information about Toda embroidery was collected. The respondents were selected from different Toda munds (settlement). They were women because Toda embroidery was done only by women. 100 respondents were randomly selected from those who were engaged in Toda embroidery. The study was conducted in four Toda Munds (settlements) namely Manjakalmund, Tarnadmund, Muthinadmund and Bettumund because of the high concentration of the Todas on the upper Nilgiri plateau. The investigator collected the information from the available literature and by having discussions with the people. Tribal Research Centre (TRC)

provided proper guidelines to reach the Toda Munds. From the women who were engaged in doing Toda embroidery, 100 respondents were randomly selected 


\section{Tools for Collecting Data}

To collect the data from the community, the investigator used the interview and observation method. The information collected through survey has been divided into two, namely general information of the respondents and specific information about Toda embroidery. The interview schedule used for the survey is given in Appendix I

\section{RESULTS}

The collected information is shown in table 1

Table 1: General Information of the Respondents

\begin{tabular}{|c|c|c|c|}
\hline SL.NO & General Information & Category & Percentage of Respondents \\
\hline \multirow{5}{*}{1} & \multirow{5}{*}{ Age } & Below 20 & $5 \%$ \\
\hline & & $20-30$ & $25 \%$ \\
\hline & & $30-40$ & $35 \%$ \\
\hline & & $40-50$ & $20 \%$ \\
\hline & & Above 50 & $15 \%$ \\
\hline \multirow{2}{*}{2} & \multirow{2}{*}{ Type of family } & Joint family & $70 \%$ \\
\hline & & Nuclear family & $30 \%$ \\
\hline \multirow{4}{*}{3} & \multirow{4}{*}{ Educational level } & Illiterate & $10 \%$ \\
\hline & & High school & $31 \%$ \\
\hline & & +2 & $29 \%$ \\
\hline & & Graduate and above & $30 \%$ \\
\hline \multirow{5}{*}{4} & \multirow{5}{*}{ Name of profession } & Cattle rearing & $45 \%$ \\
\hline & & $\begin{array}{l}\text { Agriculture related } \\
\text { Activity }\end{array}$ & $25 \%$ \\
\hline & & Embroidery work & $15 \%$ \\
\hline & & $\begin{array}{l}\text { Government/Private } \\
\text { Employment }\end{array}$ & $13 \%$ \\
\hline & & Unemployed & $2 \%$ \\
\hline
\end{tabular}

The above Table indicates that $70 \%$ of the respondents were from joint family and only $30 \%$ were from nuclear families.

The majority were in the age group of 20-50. Out of which $35 \%$ were about $30-40$ years of age. $25 \%$ belongs to $20-30$ years and $20 \%$ were falling in the age group of $40-50.15 \%$ of the respondents came under the age group of above 50 . Only $5 \%$ belongs to below 20 years.

The main occupation of Toda family was cattle rearing and related activities. Among the respondents, $45 \%$ were engaged in these activities. $15 \%$ of the respondents were engaged in making products from Toda embroidery. $25 \%$ were engaged in agricultural related activities. $13 \%$ were employed in the Government and Private agencies. Only $2 \%$ of the respondents were unemployed and were involved in some miscellaneous activities.

\section{Specific Information on Toda Embroidery}

Toda embroidery is unique to the Toda Tribal community of the Nilgiri Hills in Tamil Nadu. The embroidery they make is called Toda embroidery. Their traditional embroidered shawl is called 'Puthkuli' (Plate-1-2). All the respondents were doing embroidery on a part time basis. It was told that this art is being inherited from their elders. 


\section{Raw Materials Used}

The main raw material used were hand woven unbleached cotton fabric, needle and two ply woollen embroidery thread. The fabrics were purchased from Karoor, near Tirupur Tamil Nadu. The women were ordering the fabric as a bundle of 1000 meters. The fabric is also available as small quantities from the Ooty local market and Today's Handicraft Sale Emporium Udhagamandalam. The traditional 'puthkuli' shawls with red and black border were also purchased from Karoor and Ooty local market. The thread and needles were purchased from local markets. The main colors of embroidery thread used were red and black. Sometimes blue colour was also used.

The base cloth, half white indicates innocence; the red depicts adolescence and the black maturity. The motifs are inspired by nature and daily life. The main motif is the buffalo horn as the Todas worship buffaloes. Other designs include wild flower, mountains and valleys.

\section{Technique of Doing Toda Embroidery}

There is no particular source of design for embroidery. The designs were passed from generation to generation. The new generation is continuing to use the existing designs. It was very striking and surprising that the embroidery is done without transferring the design onto the fabric surface, and also not referring any book. The unbleached nature of hand woven cloth helps in identifying the yarn gauge quite easily. The designs were embroidered by the combined method of darning, counting of yarn gaps. The resultant design emerges as geometric form.

\section{Designs and Motifs}

The respondents were asked about the different designs used for the embroidery. Toda embroidery is based on geometric designs and they were not using any other type of designs. The motifs have given the name of Toda languages. In Toda language Puhur means flower. The motifs used are Huts (zigzag lines), the Booth Puhur combination of heart shaped design and dots), Kinask (heart shaped designs), EshPuhur (arrow shaped design), PothPuhur (diamond shaped designs), Mad Puhur (triangle shaped designs), KosePuhur (Diamond and cross), PeeshPuhur (heart shaped design), KebPuhur (triangle shaped design), PishPuhur (cross shaped motif), KoodPuhur (Diamond shaped motif), Thur Puhur('W' designs), etc. (Plate 3-14).

In traditional 'Puthkuli' shawl, the 'Thur' Puhur ('W' designs) motifs are placed in the middle, and borders are decorated with other designs. They are using their traditional shawls in their ceremonial occasions like marriage, death festivals etc.

The Toda embroidery has been given G. I certification, no changes or modification in the design have allowed.

\section{Design Documentation}

With the help of the Nilgiri Adivasi Welfare Association (NAWA) all the embroidery designs were scanned and recorded as a booklet for easier reference. 


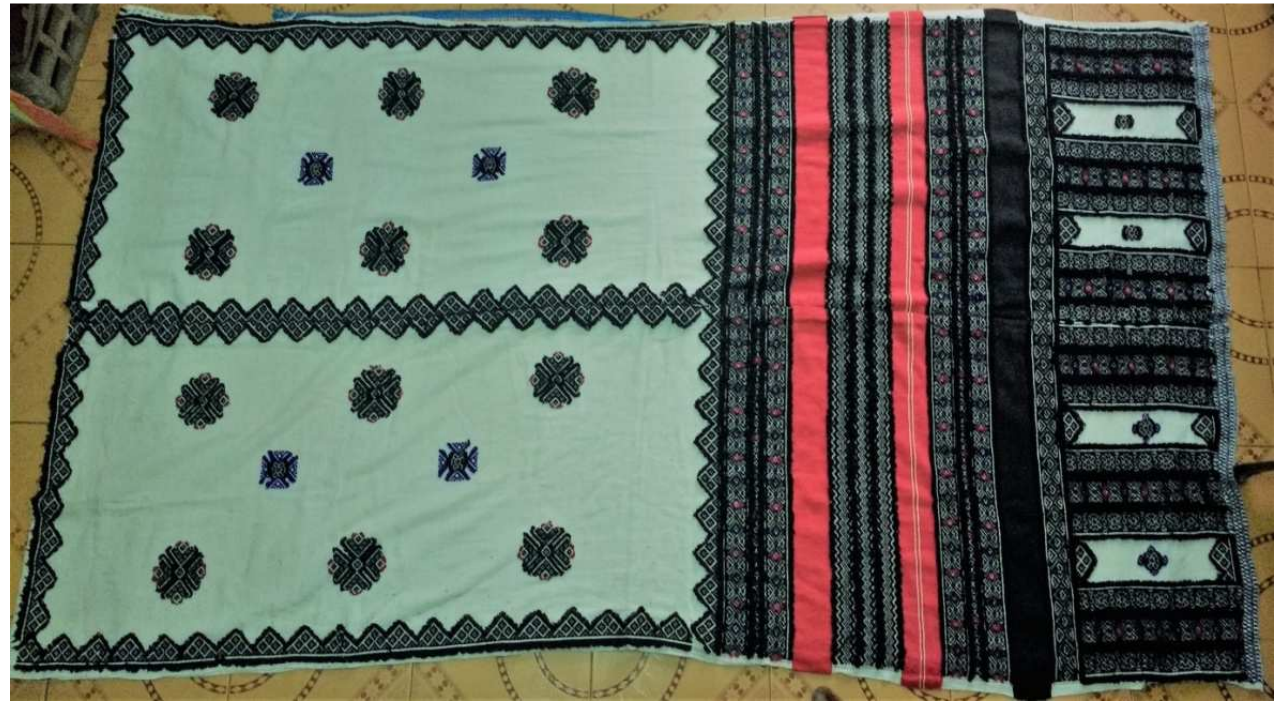

Plate 1: Traditional "Puthkuli" Shawl

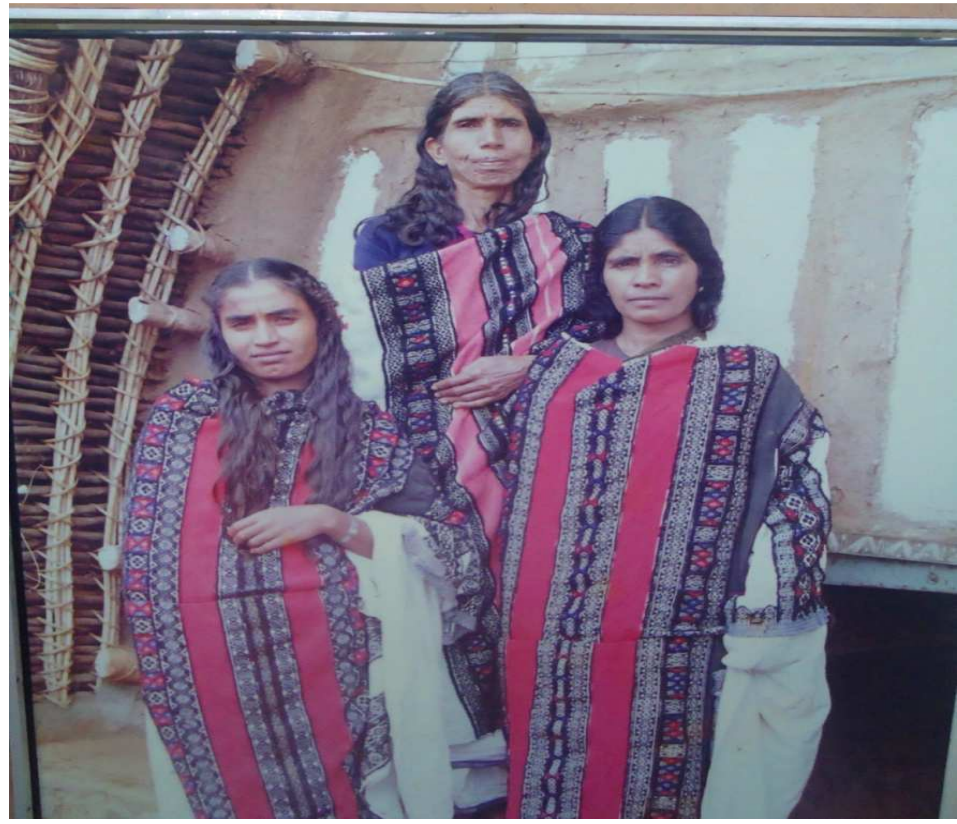

Plate 2: Toda Women in Their Traditional "Puthkuli" Shawl 


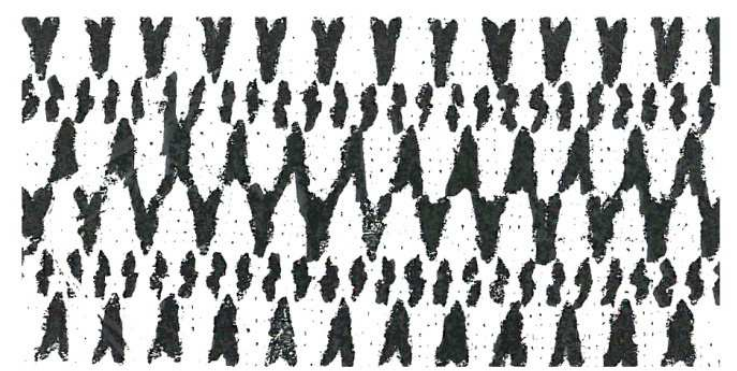

Plate 3: Huts

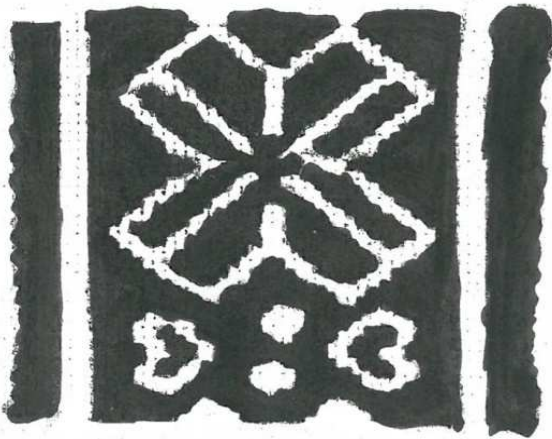

Plate 4: Booth Puhur

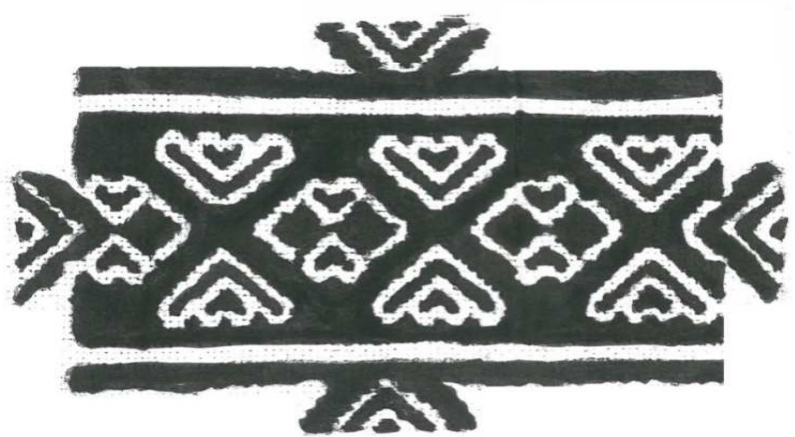

Plate 5: Kinask

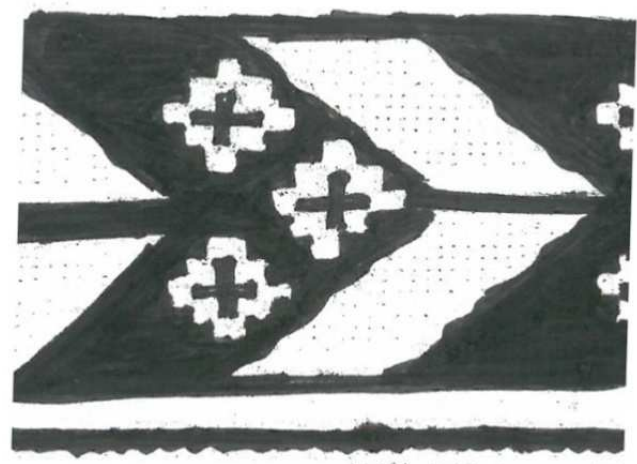

Plate 6: EshPuhur 


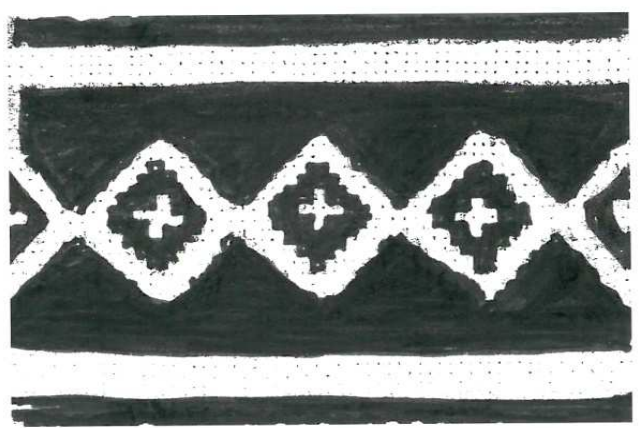

Plate 7: PothPuhur

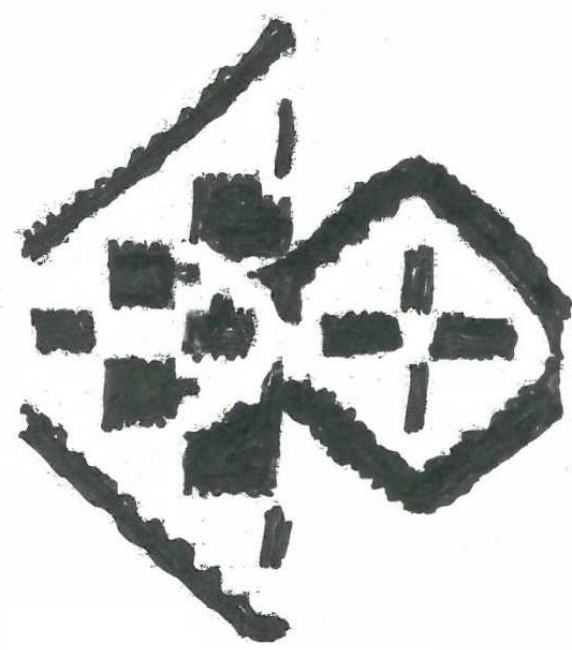

Plate 8: Mad Puhur

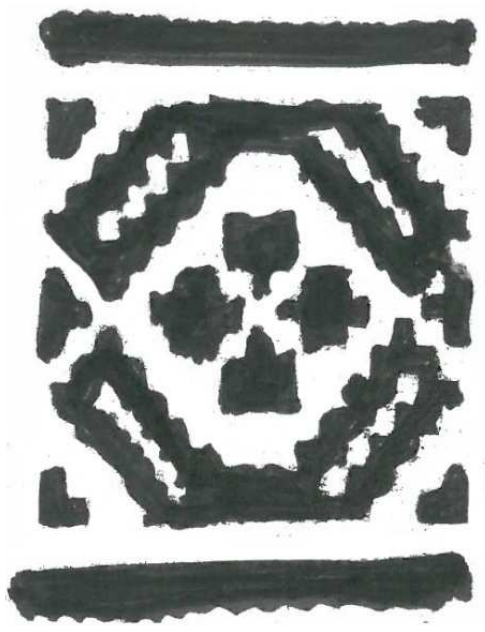

Plate 9: KosePuhur 

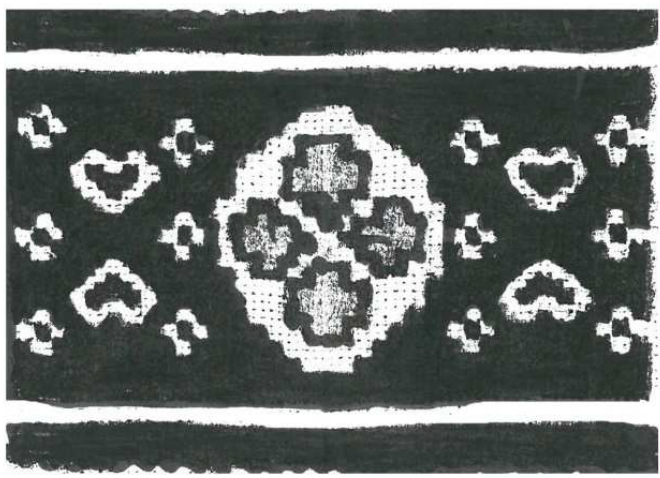

Plate 10: PeeshPuhur

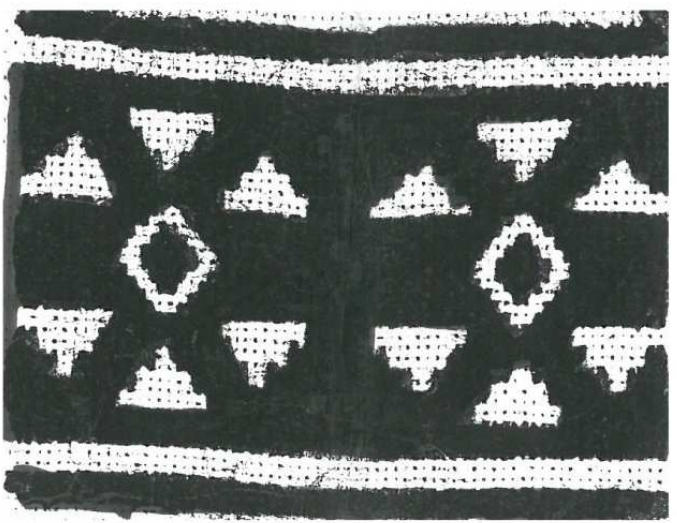

Plate 11: KebPuhur

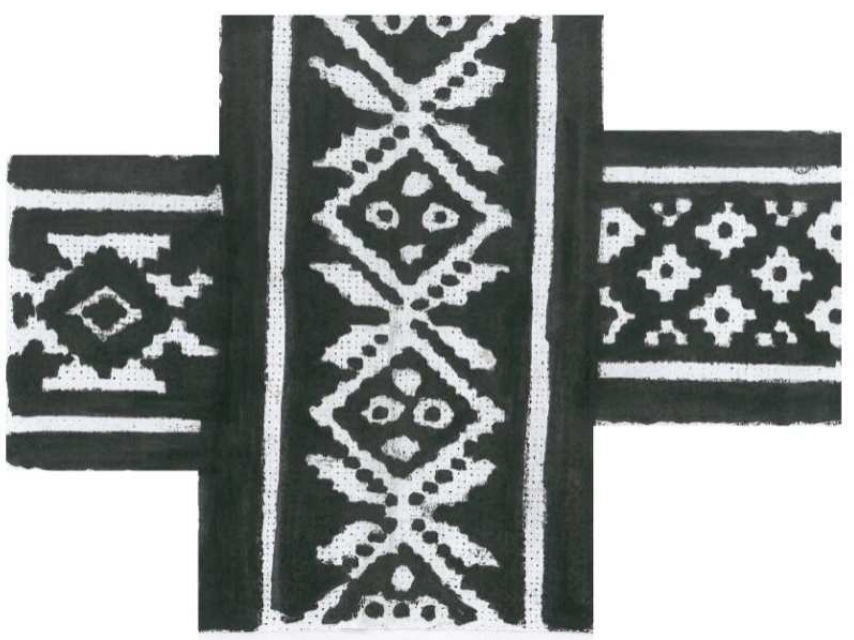

Plate 12: PishPuhur 


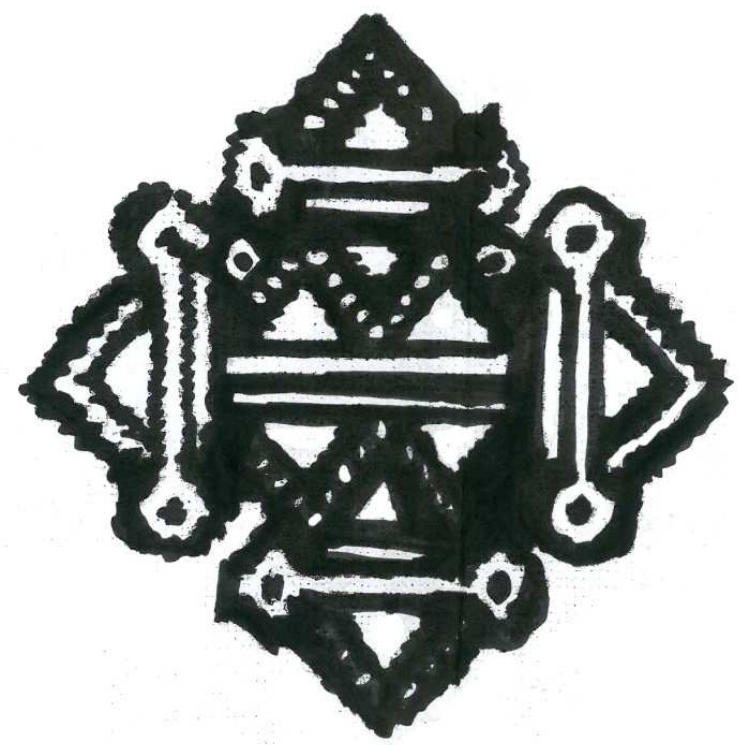

Plate 13: KoodPuhur

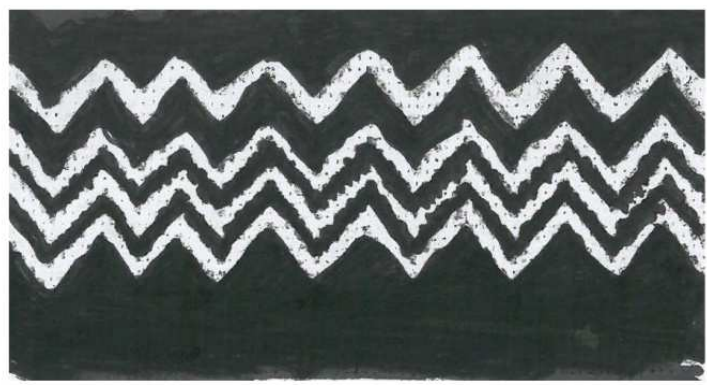

Plate 14: ThodPuhur

\section{Time Required for Embroidery}

It was reported that the respondents were not spending specific time for embroidery, but they were doing embroidery as and when they get the time. They were doing this embroidery for preserving their tradition and also for earning for some income. (Plate 15-16)

The different kinds of products they are making and required time of completion of each product is shown in the Table 2.

Table 2: Different Products and their Required Time for Completion

\begin{tabular}{|l|c|}
\hline \multicolumn{1}{|c|}{ Item } & Required time \\
\hline Traditional puthkuli & $75-80$ days \\
\hline Shawls & 22 days \\
\hline Dupatta & 15 days \\
\hline Cell phone pouch & 3 days \\
\hline Table cloth & 5 days \\
\hline Purse & 2 days \\
\hline Wall hangings & 4 days \\
\hline Cushion cover & 3 days \\
\hline Shoulder bag & 4 days \\
\hline
\end{tabular}




\section{Assistance from Government and Private Agencies}

Toda embroidery got GI (Geographical Identification) in September 2013. GI is a sign used on goods that have a specific geographical origin and possess qualities, reputation or characteristic that can be attributed to that place of origin. The GI registration was a great help for the marketing of the product.

Todas are getting assistance from TamilNadu Government and other NGO' $\mathrm{s}$ to market their embroidered products. There are self-help group in Munjakalmund, which contains 16 members. They are selling their embroidered products in a small retail outlet in the Botanical garden. The outlet is sponsored by the Government of TamilNadu at free of rent. (Plate 17-20)

The 'Todas Handicraft sale emporium' is run by TamilNadu Government, which also helps to market these products.

With the help of the Office of the Development Commissioner (Handicrafts), Ministry of Textiles, Government of India under the 'AmbedkarHastashilpVikasYogana (AHVY) scheme, the craft has taken a new shape. The Traditional craft has been viewed and introduction of diversified products like shoulder bag, picture frame, note book and other products of varied designs have come into existence.

The NilgiriAdivasi Welfare Association (NAWA) is implementing promotional activities to motivate Toda women for making embroidered products. The Nilgiri Hills has expertise in marketing, design development and handicraft exhibitions and other promotional activities in order to help the growth of the empowerment of Toda women and preserving the art of Toda embroidery.

The Kotagiri women's co-operative cottage industrial society Ltd. sells the various embroidered products. They are providing innovative and creative ideas to Toda women to increase the demand of the products. (Plate 21)

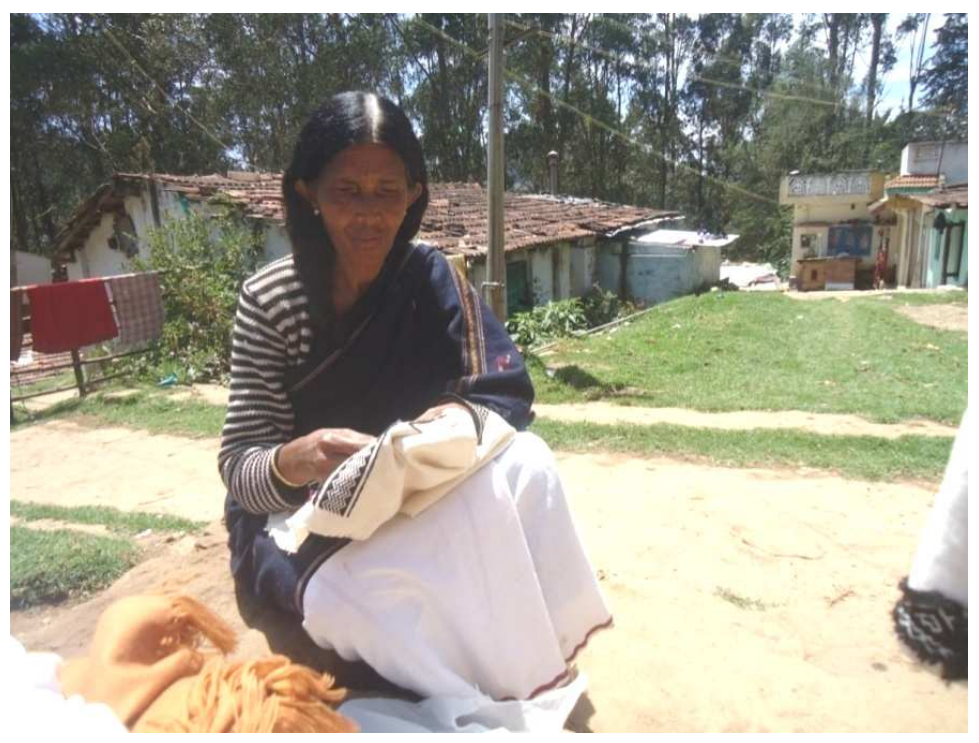

Plate 15: Toda Woman Doing Embroidery (Manjakalmund) 


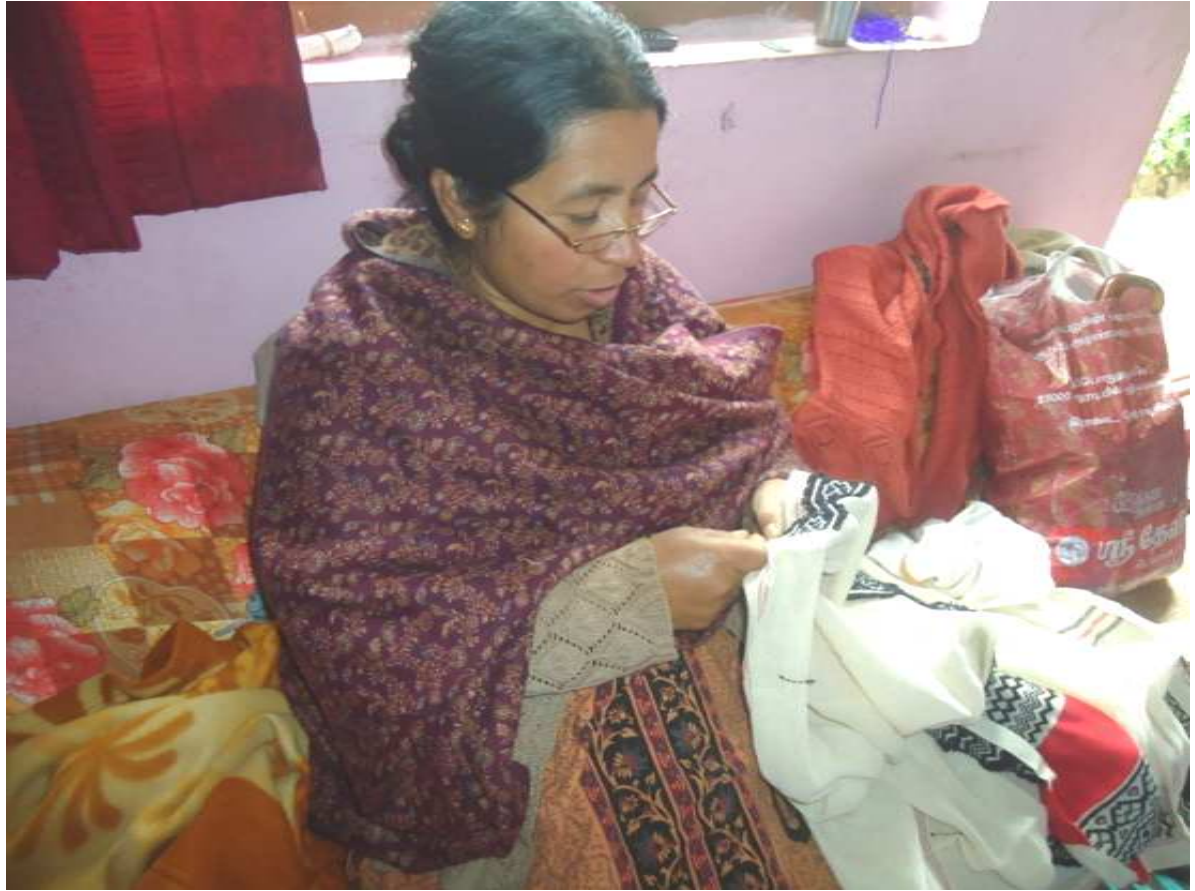

Plate 16: Toda Woman Doing Embroidery (Muthinadmund)

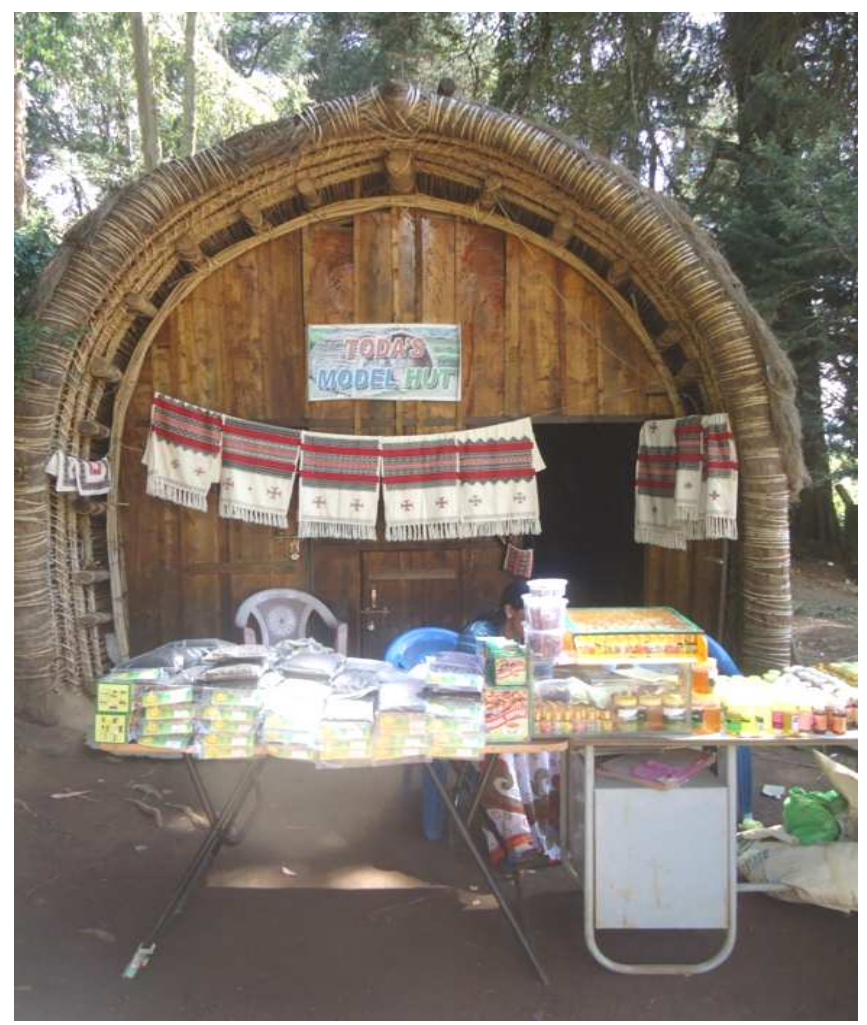

Plate 17: Retail Outlet in the Botanical Garden Sponsored by the Tamilnadu Government 


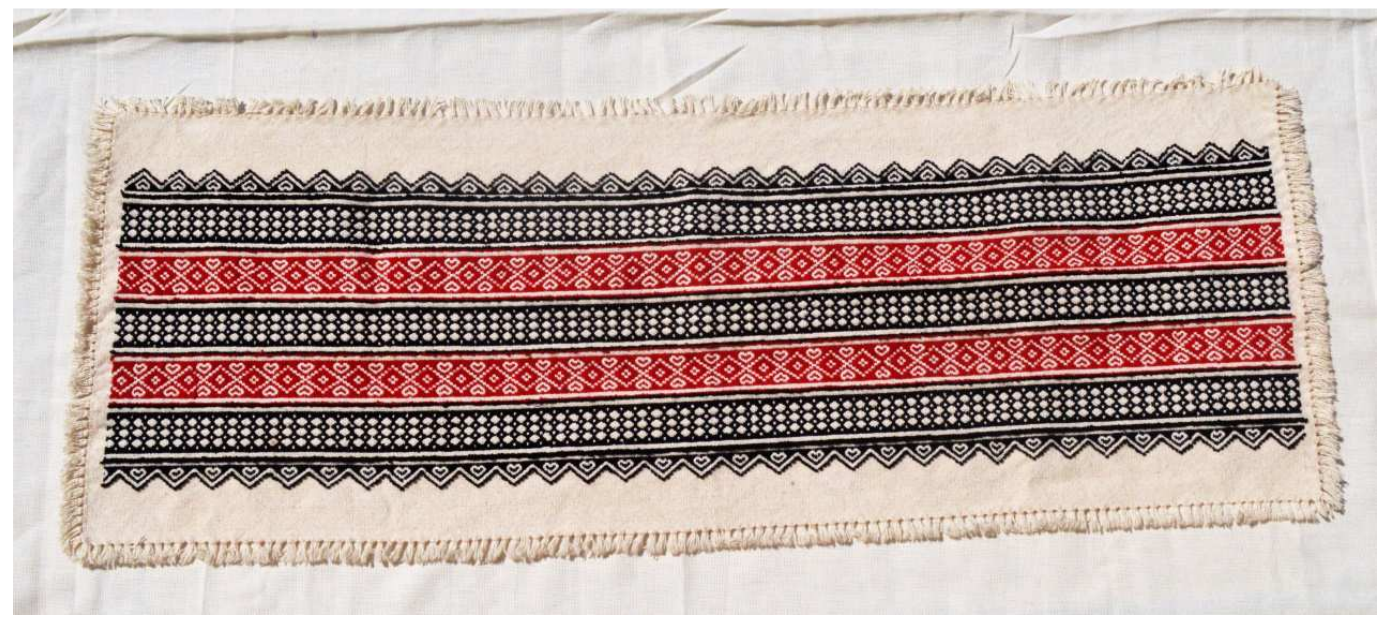

Plate 18: Toda Embroidered Table Mat for Sale at Retail Outlet in the Botanical Garden

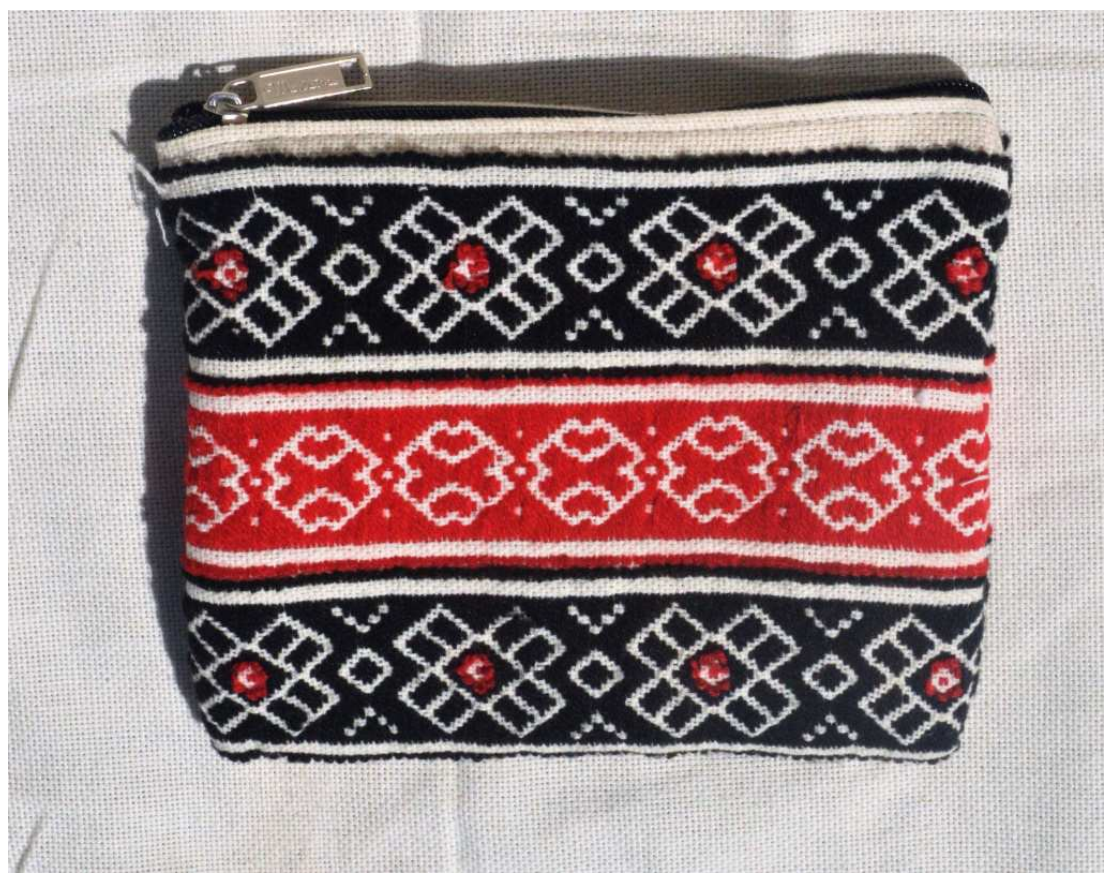

Plate 19: Toda Embroidered Pouch for Sale at Retail Outlet in the Botanical Garden 


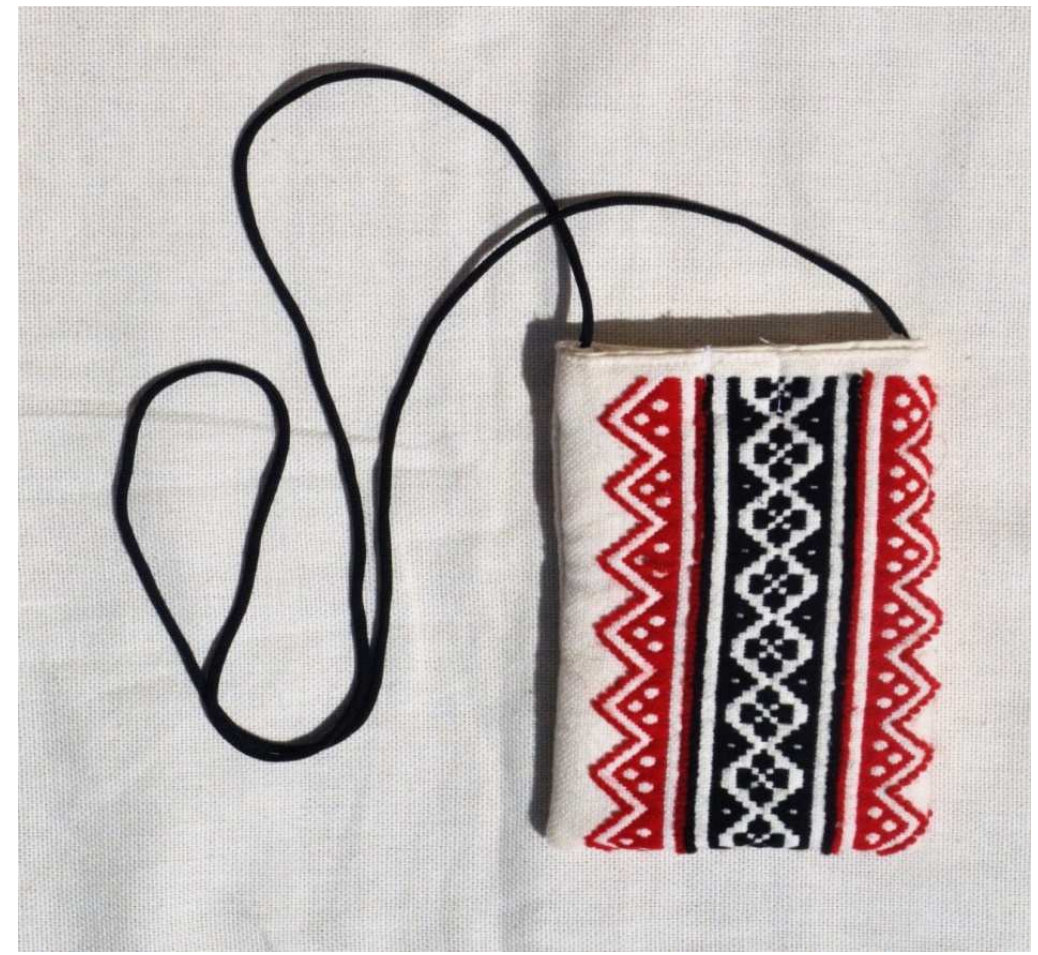

Plate 20: Toda Embroidered Cell Phone Pouch for Sale at Retail Outlet in the Botanical Garden

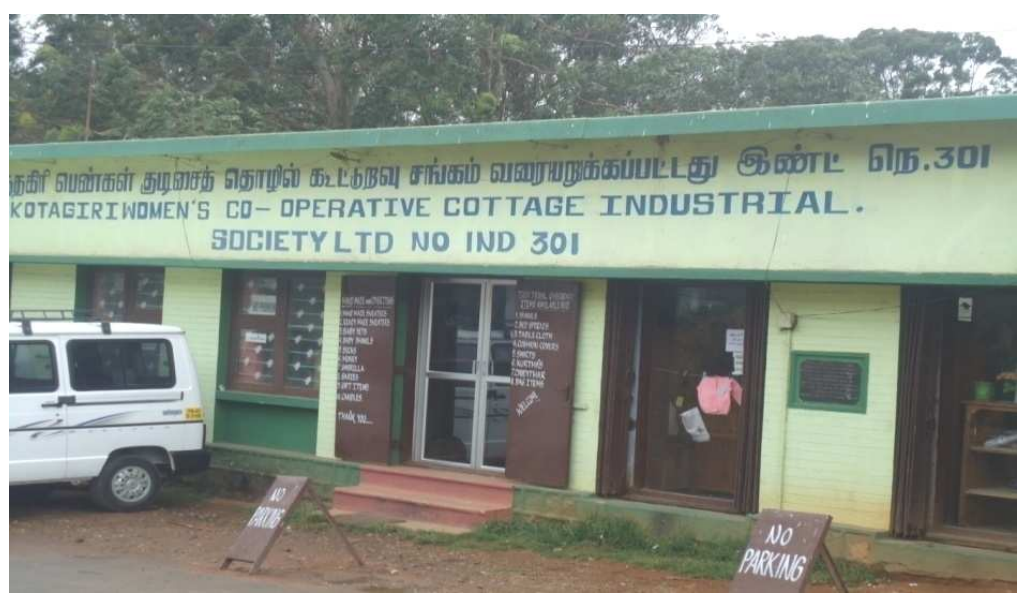

Plate 21: The Kotagiri Women's Co-Operative Cottage Industrial Society

\section{CONCLUSIONS}

The present study was undertaken with the aim to study socioeconomic culture of Todas in the Nilgiri district of Tamil Nadu, and their traditional Toda embroidery. Four Toda munds (settlements) namely Manjakalmund, Tarnadmund, Muthinadmund and Bettumund were selected for the study. 100 respondents were randomly selected and data were collected through a survey using observation and interview method. The sample size was 150 respondents.

A questionnaire was formed on the basis of the general information, i.e. age, type of family, educational level, and specific information regarding Toda embroidery i.e. technique of representing the artist, the raw material used, significance 
of symbols, motifs, sourcing of raw materials and marketing of the products.

\section{General Information of the Respondents}

Among the respondents most of them belonged to the age group of $30-40$ years $(35 \%) .70 \%$ of the respondents belonged to joint family. As far as the education was concerned, $31 \%$ had studied till high school. 30\% were graduate, $29 \%$ studied up to $+2.10 \%$ were illiterate. It was also found that $45 \%$ of the respondents were engaged in cattle rearing. $25 \%$ were engaged in agriculture related activity. $15 \%$ of the respondents were engaged in embroidery work. Government and private employment were $13 \%$ and $2 \%$ were unemployed.

\section{Specific Information on Toda Embroidery}

It was observed that all the respondents were doing embroidery on a part time basis. Some of the signs as well as the relevant findings showed that $100 \%$ of the respondents inherited this art from their elders.

The main raw materials used were unbleached cotton fabric, needle and wool embroidery thread. The fabrics were purchased from Karoor. Needle and woollen threads were purchased from local markets. The main colours of embroidery thread used were red, black and blue. There is no particular source of design for embroidery. The designs were passed from generation to generation.

Toda embroidery is based on geometric designs. The motifs used were; Huts (zigzag lines), thurpugur ('W' designs), H-puhur (H shaped designs), pothpuhur (diamond shaped designs), Kinask (heart shaped designs) etc. The motifs were inspired from nature and daily life. The main motif is the buffalo horn as the Todas worship buffaloes. Other designs include Wild Flowers Mountains and valleys. They don't attach any significance for any design.

The respondents were not spending specific time for embroidery, but they were doing embroidery asthey get the time. They were spending more time for their traditional 'puthkuli' shawls (75-80 days) and do this for preserving their traditions and also for earning some money.

Toda embroidery got GI (Geographical Identification) in September 2013. Todas are getting assistance from Tamilnadu Government and other NGO's to market their embroidered products.

The majority of respondents preferred to have Toda embroidery designs on women's kurtis. However, they do not want to change the traditional fabric and design.

In India, Todas are found only in the Nilgiri District of Tamil Nadu State. Toda Tribes are very seclusion in nature and very few people know about this tribe and their unique embroidery. Few efforts are being taken by the government and other NGO's to preserve Toda embroidery art. The present study was planned to help Todas to showcase their skills to the outside world.

\section{REFERENCES}

1. Chhabra, Tarun(1992) Toda Festivals, The Hindu July:12.

2. Chhabra, Tarun(1993) The journey to the Toda afterworld, in The India Magazine 13(1):8-17

3. CossMelinda(1996) The DMC book of embroidery.

4. Parthasarathy, Jakka (2005) Todas of the Nilgiri hills:Anthropological Reflections on Community survival, Director of Museums, Govt of Tamil Nadu, Chennai. 
5. River, W.H.R.(1906) TheTodas, Macmillan and Co.

6. Walker, R. Antony (1989) Toda Society betweenTradition and Modernity, in Blue Mountains, ed. By Paul Hockings, Oxford University Press, New York.

7. Marshall E.Wiiliam (1995) A phrenologist amongst the Toda.

\section{APPENDIX - II}

\section{Questionnaire}

\section{Socio Economic Background}

- Name of the respondent.

- $\quad$ Age \& Sex

- $\quad$ Family Type

- Nuclear

- Joint

- $\quad$ Educational level

- Illiterate

- High school

$-\quad+2$

- Graduate and above

- What is your occupation?

- Cattle rearing

- Agriculture

- Embroidery work

- What is your income per month?

- Whether the earnings are sufficient to fulfill the needs of the family?

- Which language do you speak?

\section{SPECIFC INFORMATION ON TODA EMBROIDERY}

- What is the specific name of your Tribal Embroidery?

- Is it your main occupation or part time occupation?

- How did you learn the art of embroidery?

- Inherited

- $\quad$ Acquired 
- What are the raw materials do you use to embroider products?

- Fabric

- $\quad$ Embroidery thread

- Needle

- Embroidery frame

- $\quad$ Tracing paper

- $\quad$ Any other

- Is this embroidery done for earning money or as a hobby?

- What kind of fabrics do you use in embroidery work?

- Cotton

- Wool

- $\quad$ Silk

- Synthetic

- Any other

- Do you use different colour for Embroidery?

- If yes what are the colors?

- From where do you purchase the raw materials?

- Import

- Through Agents

- $\quad$ Local Market

- Any other

- What are the common motifs used

- Geometric

- Abstract

- Religious

- $\quad$ Stylized

- Natural

- Any Other 
- Is there any significance in using any motif?

- What are the sources of design?

- Own design

- $\quad$ Copying existing designs

- From books

- Any other

- How do you transfer your designs on the fabric?

- Using tracing paper

- $\quad$ Free hand drawing

- $\quad$ Any other

- What are the different stitches used to ornate the designs?

- How much time do you spent for embroidery

- 12 Hours

- 6 Hours

- 3 Hours

- Less than 3 hours

- What are the different types of products do you embroider?

- Shawl

- Wall Hangings

- Pouch

- Table Cloth

- Handicrafts

- $\quad$ Any other

- What is the time required to complete each products?

- Shawl

- Wall Hangings

- Pouch

- Table Cloth

- Handicrafts 
- Any other

- What is the purpose of doing this Embroidery?

- For specific occasion

- Festivals

- Religious activity

- $\quad$ Any other

- Do you sell your products?

- If yes where do you sell the products?

- What is the selling price?

- Shawl

- Wall Hangings

- Pouch

- Table Cloth

- Do you get any help from Govt. agencies or Tribal Board?

- If yes what kind of assistance do you get from them?

- Is there any NGO's helping you in making products?

- Do you hire any designers for your embroidery?

- Do you have design library

- Would you like to introduce some changes in this embroidery?

- If yes in what

- Designs

- Fabric

- $\quad$ Arrangements of motif

- $\quad$ Thread

- Colour

- Would you like to introduce this embroidery on women's kurtis 